\title{
FIBRIN GLUE IN THE MANAGEMENT OF COMPLEX ANAL FISTULA
}

\author{
Daniel C. DAMIN ${ }^{1,2}$, Mário A. ROSIT01,2, Paulo C. CONTU1,2 and Cláudio TARTA ${ }^{1,2}$
}

\begin{abstract}
Context - Management of complex anal fistulas is associated with the risk of sphincter injury and fecal incontinence. In recent years, fibrin glue has emerged as an alternative sphincter-preserving treatment for anal fistulas. To date, however, there is no consensus about the efficacy of the method. Objective - To specifically evaluate the fibrin glue injection in the management of complex cryptoglandular anal fistulas. Methods - We studied a series of patients with complex anal fistulas treated with fibrin glue between January 2005 and January 2007. Only patients with fistulas of cryptoglandular origin were analyzed. Patients with fistulas related to Crohn's disease, HIV or previous surgery were excluded from the study. Under spinal anesthesia, the fistulas were curetted and injected with fibrin glue. After treatment, patients were followed-up for 12 months. Results - Thirty-two patients were enrolled in the study. Two patients were lost to follow-up and were excluded. Out of the remaining 30 patients, only three healed successfully $(10 \%)$. Among the 27 patients who failed to heal, $9(33.3 \%)$ were diagnosed within the first postoperative month. In 13 patients (48.1\%) the failure of treatment occurred in the period between 1 and 3 months, in 3 patients $(11.1 \%)$ between 3 and 6 months, and in 2 patients (7.4\%) between 6 and 9 months after surgery. No treatment-related complications were observed. Conclusions - In this series, fibrin glue treatment for complex cryptoglandular anal fistulas achieved a very low healing rate. Our results do not support the use of fibrin glue as a first-line treatment for patients with this type of fistula.
\end{abstract}

HEADINGS - Rectal fistula. Fibrin tissue adhesive. Tissue adhesives.

\section{INTRODUCTION}

The term "complex" anal fistula, which is a modification of the original Parks classification, refers to those fistulas in which treatment by a simple laying open procedure would result in a significant impairment of continence ${ }^{(17)}$. An anal fistula of cryptoglandular origin may be described as complex when the track crosses more than $30 \%-50 \%$ of external sphincter (high transsphincteric or suprasphincteric fistula), when is anterior in a female or has multiple tracks ${ }^{(17,21)}$.

The objective of fistula surgery is to eradicate the fistula tract while preserving sphincter function. This is particularly difficult to achieve when the fistula is complex. Traditionally, cutting setons have been used to promote a staged division of the sphincters while inducing gradual perisphincteric fibrosis and muscular healing ${ }^{(21)}$. Although this technique has low recurrence rates $(0 \%-8 \%)$, it is associated with significant rates of minor (34\%-63\%) and major fecal incontinence (2\%$26 \%)^{(8,9,18,21,22)}$. For these reasons, cutting setons have been progressively replaced by endorectal advancement flap in the treatment of complex fistulas. Successful healing has been demonstrated in 55\%-98\% of patients submitted to the procedure. Although the sphincter mechanism is not divided during the construction of the endorectal flap, minor incontinence has been reported in up to $31 \%$ of the patients and major incontinence in up to $12 \%(2,12,16,21)$.

In this context, fibrin glue injection has emerged as an attractive sphincter-conserving treatment for anal fistula. The procedure is very easy to perform, has no significant morbidity and preserves continence without compromising future surgical treatments ${ }^{(6)}$. However, the success rates of the fibrin glue injection have range from $0 \%-100 \%{ }^{(10)}$. Such a wide variation seems to result from differences in the etiology and complexity of the fistulas included in each series, as well as from variable sample sizes and duration of patient follow-up ${ }^{(10,20)}$. In the present study, we evaluate the efficacy of the fibrin glue treatment in patients with complex cryptoglandular anal fistulas.

\section{METHODS}

\section{Study design}

We studied prospectively a series of consecutive patients with complex (high transsphincteric) anal fistulas primarily treated with fibrin glue injection between January 2005 and January 2007. Only patients with fistulas of cryptoglandular origin were enrolled in the study. None of the patients presented acutely inflammed fistulas. All fistulas were chronic and presented "mature" tracts. High transsphincteric fistulas were 
defined as those fistulas encompassing more than one-third of the external sphincter in which the clinical evaluation judged that a simple fistulotomy would result in fecal incontinence ${ }^{(17)}$. Patients with simple fistulas or those with complex fistulas related to Crohn's disease, HIV or previous surgery were not included in the study. Fistulography was used to determine fistula extension and exclude high blind tracts.

The study was approved by the Ethics and Scientific Committee of the "Hospital de Clinicas de Porto Alegre", Federal University of Rio Grande do Sul, Porto Alegre, RS, Brazil. All patients provided written informed consent before participating in the study.

\section{Surgical technique}

Patients were examined under spinal anesthesia in the lithotomy position. No specific bowel preparation was used and a single dose of antibiotics against gram-negative and anaerobic organisms was administered before the surgery. A thorough anorectal examination was performed. The internal primary opening was located by gentle probing of the tract and the anatomy and complexity of the fistula were determined. In all cases the fistula length was longer than 3 $\mathrm{cm}$. High blind tracts, as well as multiple tracts, were excluded in all patients. Hydrogen peroxide was routinely used in those cases in which the internal opening was not promptly found by probing. A 3-0 Vicryl suture was placed, but not tied, at the internal orifice in a figure-of-eight fashion.

The tract was debrided with a curette or a gauze sponge to remove any pus or granulation tissue within the fistula. Fibrin glue was prepared according to manufacturer's recommendations (Tissucol ${ }^{\circledR}$ Fibrin Sealant, Baxter, Vienna, Austria). A flexible catheter was inserted into the fistula through the external opening and was passed into the anal canal. Fibrin glue was slowly instilled using a double-channel injector until a bed of sealant was formed at the internal opening (Figure 1).

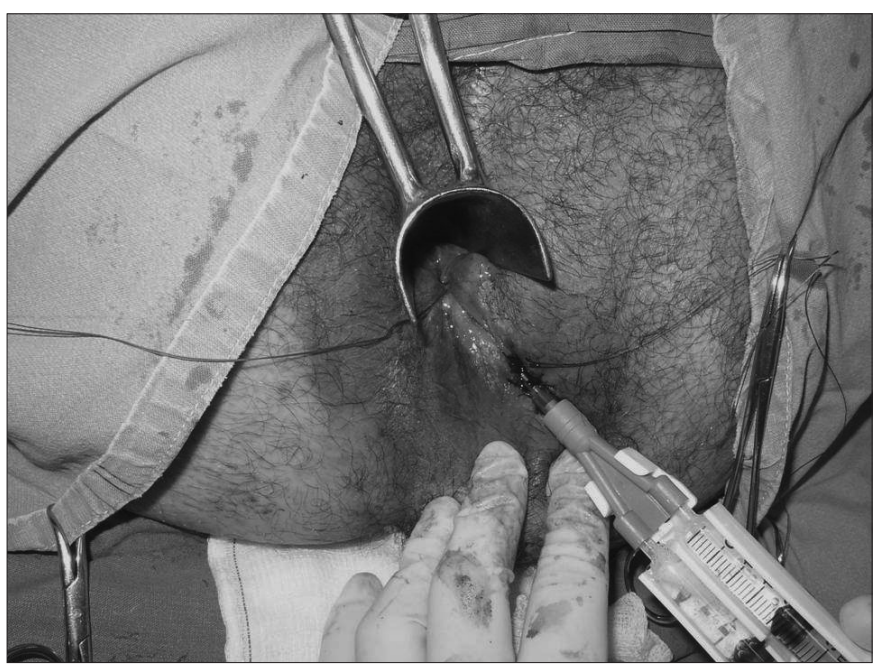

FIGURE 1. Fibrin glue being instilled through the external opening of a fistula using the double-channel injector. A Vicryl suture was placed at the internal orifice inside the anal canal
Next, the catheter was slowly withdrawn while the tract was completely filled with glue. The application was concluded with placement of a second large bed of sealant at the external orifice. Finally, the suture at the internal opening was tied completing the procedure. In some cases, a Vicryl suture was also used to close the external orifice (Figure 2). Patients were discharged after few hours. They were instructed not to take sitz baths and to avoid physical activity for at least 2 weeks.

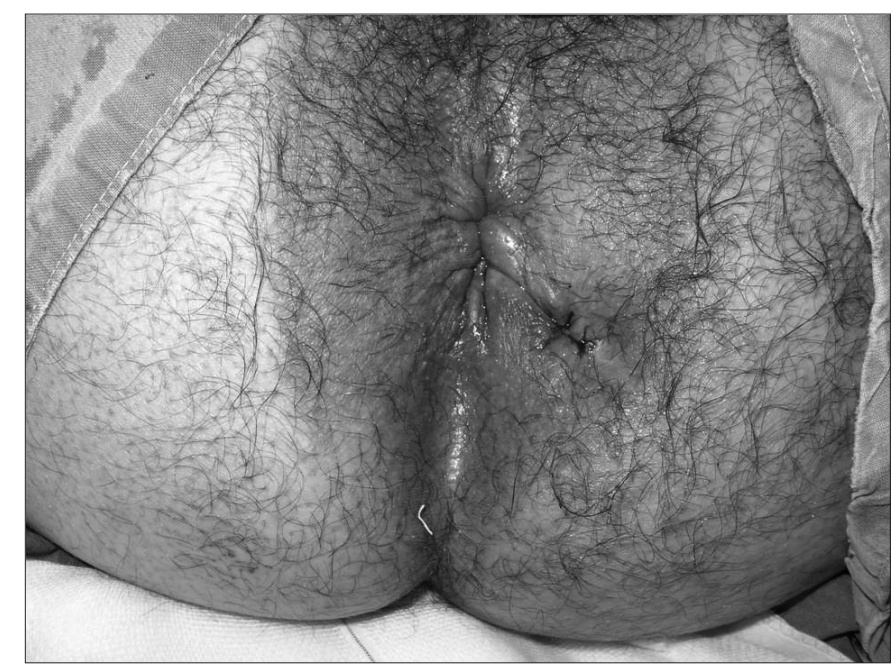

FIGURE 2. Aspect of the perineum after completion of the procedure. The anatomic integrity of the anal canal is entirely preserved

\section{Follow-up}

Patients were initially examined at the office 4 weeks after surgery to assess wound healing. Specific follow-up information was derived from clinical evaluation at 3, 6, 9, and 12 months postoperatively. During each follow-up visit patients were specifically questioned about drainage from the fistula site and submitted to physical examination. Treatment failure was defined as drainage through the original external orifice of the fistula. Successful healing was defined as no recrudescence of drainage at the last follow-up visit.

\section{RESULTS}

A total of 32 patients were initially enrolled in the study. Two of these did not complete the scheduled postoperative follow-up and were excluded. The remaining 30 patients comprised the study group (16 males; median age 37 (range, 23-62) years). One patient had previously had a draining seton placed during a primary drainage of a large anal abscess before the fibrin glue treatment. All the other patients had no previous specific treatment of their fistulas.

After completion of the 12-month follow-up, successful healing was achieved in only three patients $(10 \%)$. Of the 27 patients $(90 \%)$ who failed to heal, $9(33.3 \%)$ were diagnosed within the 1 st month after surgery. In 13 patients $(48.1 \%)$ the failure of the fibrin glue injection was identified in the period 
between 1 and 3 months, in 3 patients (11.1\%) between 3 and 6 months, and in 2 patients $(7.4 \%)$ between 6 and 9 months after treatment. No fistula recurrence was observed after the 9th postoperative month.

No complications, such as abscess formation at the fistula site, incontinence, or development of a more complex anal fistula, were seen with the fibrin glue treatment.

\section{DISCUSSION}

Management of complex anal fistulas is notoriously one of the most difficult problems to deal with in coloproctological surgery ${ }^{(7,17)}$. Traditional treatments, including the use of cutting setons and advancement flap repairs, have been shown to be effective in promoting fistula healing. However, these methods have also been related to significant rates of sphincter impairment and anal incontinence ${ }^{(21)}$.

Over the last 2 decades, fibrin glue injection has been investigated as a potential first-line therapy for anal fistula. This treatment modality is appealing because it carries no risk of incontinence associated with division of sphincter muscles. It is safe and easy to perform, avoids open perineal wounds, and does not interfere with future surgical treatments if necessary ${ }^{(10,14)}$. The efficacy of the fibrin glue injection, however, remains in question. While some authors have reported healing rates as high as $85 \%$, others failed to obtain any long-term healing $(0 \%)$ using the technique ${ }^{(10,19)}$. These discrepant results are likely due to differences in complexity and etiology of the fistulas included in each series. There are also significant variations in length of postoperative followup among the published reports.

In the present study, we tried to exclusively address the efficacy of the fibrin glue treatment in patients with anal fistulas of cryptoglandular origin. We elected not to include fistulas related to other etiologies, such as Crohn's disease or HIV infection, since these lesions tend to have a different clinical behavior and response to surgical treatment ${ }^{(10,11,20)}$. We also restricted our analysis to complex fistulas, because in our surgical practice we do not routinely use fibrin glue for treatment of simple fistulas, which are usually managed through simple fistulotomy. Except for one patient who had a seton inserted during drainage of an ischeoanal abscess, none of our patients had been previously submitted to a fistula treatment.

These specific inclusion criteria may, in part, explain the low success rate $(10 \%)$ we obtained with the fibrin glue treatment, since our surgical technique does not differ from techniques used by other authors ${ }^{(16,17,22)}$. Our results are in line with the findings of BUCHANAN et al. ${ }^{(3)}$, who studied 22 patients with complex cryptoglandular fistulas submitted to fibrin glue injection. Their study included 19 patients $(86.5 \%)$ with transsphincteric fistulas, 1 patient (4.5\%) with a suprasphicteric fistula, and 1 patient $(4.5 \%)$ with an extrasphincteric fistula. After a follow-up period of 16 moths, only 3 patients (14\%) did not develop fistula recurrence, remaining asymptomatic. Similarly, LOUNGNARATH et al. ${ }^{(15)}$ reviewed their experience with the fibrin glue treatment of 39 patients with complex anal fistulas. The healing rate for fistulas of cryptoglandular origin was $23 \%$ ( 5 of 22 patients).

In contrast, other authors have achieved higher rates of success in treatment of cryptoglandular fistulas ${ }^{(1,13,19,23)}$. In the largest published series to date, CINTRON et al. ${ }^{(4)}$ reported a healing rate for cryptoglandular fistulas of $63 \%$, compared with $35 \%$ for fistulas of other etiologies, with a mean follow-up of 1 year. Although no study has been able to demonstrate a statistically significant difference in healing rates according to fistula etiology ${ }^{(20)}$, it is generally agreed that anal fistulas associated with Crohn's diseases or HIV are usually more difficult to heal.

In our series, $81.4 \%$ of the fistula recurrences were observed within 3 months of treatment. None of our patients presented a fistula recurrence after 9 months of follow-up. Other authors have also demonstrated that if a failure is to occur, it will do so during the initial 6 months postoperatively. Recurrence after 12 months of closure is unlikely. According to CINTRON et al. ${ }^{(5)}$, fibrin glue injection cannot be considered a success without a minimum follow-up of 1 year. Fibrin glue injection proved to be a very safe treatment. As in previous published studies, there were no treatment-related complications in our study or adverse effects on subsequent treatments.

In this series, fibrin glue treatment for complex cryptoglandular anal fistulas achieved a very low success rate. This disappointing result calls into question the use of fibrin glue as a first-line treatment for these patients. Several unfavorable aspects have to be taken into account when this method is chosen, including monetary costs, health resources, potential anesthetic risks, surgeon's time, time off from work and need for at least 1-year of postoperative follow-up. Therefore, it seems hardly justifiable to use fibrin glue as routine first surgical approach for complex anal fistulas at this time.

However, because this treatment is safe and does not compromise future surgical treatments ${ }^{(14)}$, it might exceptionally have a limited role in selected very complex cases in which sphincter impairment is highly anticipated. In this situation, patients should be clearly warned about the low success rate expected with the procedure and the potential need of subsequent treatments.

At this time there is no consensus in the literature about the efficacy of fibrin glue injection in the treatment of complex cryptoglandular anal fistulas ${ }^{[20)}$. Although investigated by different authors, fibrin glue could not be defined as the treatment of choice for anal fistulas to this moment. Studies investigating novel alternative treatments, such as anal plugs and stem cell therapy are likely to identify more efficient techniques to manage complex anal fistulas.

\section{CONCLUSION}

In this series, fibrin glue treatment for complex cryptoglandular anal fistulas achieved a very low healing rate. The results of the present study do not support the use of fibrin glue in the routine management of complex cryptoglandular anal fistulas. 
Damin DC, Rosito MA, Contu PC, Tarta C. Uso da cola de fibrina no tratamento da fistula anal complexa. Arq Gastroenterol. 2009;46(4):300-3.

RESUMO - Contexto - O manejo das fistulas anais complexas está associado ao risco de lesão esfincteriana e incontinência fecal. Recentemente, a cola de fibrina surgiu como uma alternativa de tratamento conservador de esfíncter para as fístulas anais, porém até o momento não se chegou a um consenso quanto à eficácia do método. Objetivo - Avaliar o uso da cola de fibrina especificamente no tratamento de fístulas anais complexas de origem criptoglandular. Métodos - Foram estudados pacientes com fístulas anais complexas tratados com cola de fibrina entre janeiro de 2005 e janeiro de 2008. Somente pacientes com fístulas de origem criptoglandular foram analisados, sendo excluídos pacientes com fístulas relacionadas à doença de Crohn, ao HIV ou à cirurgia prévia. Sob anestesia espinhal, as fistulas eram curetadas, sendo após preenchidas com cola de fibrina. Depois do tratamento, os pacientes eram acompanhados por 12 meses. Resultados - Trinta e dois pacientes foram incluídos no estudo. Dois pacientes foram perdidos durante o seguimento pós-operatório, sendo excluídos. Dos 30 pacientes remanescentes, apenas 3 tiveram suas fistulas cicatrizadas (10\%). Com relação aos 27 pacientes nos quais não houve cicatrização, em 9 pacientes $(33,3 \%)$ a falha do tratamento foi diagnosticado nos primeiros 30 dias após a cirurgia, em $13(48,8 \%)$ entre 1 e 3 meses, em $3(11,1 \%)$ entre 3 e 6 meses e em 2 pacientes $(7,4 \%)$ entre 6 e 9 meses após a cirurgia. Não foram observadas complicações relacionadas ao tratamento. Conclusões - Nesta série, o tratamento das fístulas anais complexas de origem criptoglandular com cola de fibrina atingiu um índice muito baixo de cicatrização. Estes resultados não permitem a indicação da cola de fibrina como tratamento de primeira escolha para pacientes com esse tipo de fístula.

DESCRITORES - Fístula retal. Adesivo tecidual de fibrina. Adesivos teciduais.

\section{REFERENCES}

1. Adams T, Yang J, Kondylis LA, Kondylis PD. Long-term outlook after successful fibrin glue ablation of cryptoglandular transsphicteric fistula-in-ano. Dis Colon Rectum. 2008;51:1488-90.

2. Aguilar PS, Plasencia G, Hardy TG Jr, Hartmann RF, Stewart WR. Mucosal advancement in the treatment of anal fistula. Dis Colon Rectum. 1985;28:496-8.

3. Buchanan GN, Bartram CI, Phillips RK, Gould SW, Halligan S, Rockall TA, Sibons P, Cohen RG. Efficacy of fibrin sealant in the management of complex anal fistula: a prospective trial. Dis Colon Rectum. 2003;46:1167-74.

4. Cintron JR, Park JJ, Orsay CP, Pearl RK, Nelson RL, Abcarian H. Repair of fistulas-in-ano using autologous fibrin tissue adhesive. Dis Colon Rectum. 1999;42:607-13.

5. Cintron JR, Park JJ, Orsay CP, Pearl RK, Nelson RL, Song R, Abcarian H. Repair of fistulas-in-ano using fibrin adhesive: long-term follow-up. Dis Colon Rectum. 2000;43:944-50.

6. Dietz DW. Role of fibrin glue in management of simple and complex fistula in ano. J Gastrointest Surg. 2006;10:631-2.

7. Fillmann LS, Pandolfo G, Fillmann HS, Born G, Fillmann EP, Hoefel Filho JR, Marques MB. O uso da ressonância magnética no diagnóstico das fistulas anais. Rev Bras Coloproctol. 2004;24:45-8.

8. Garcia-Aguilar J, Belmonte C, Wong DW, Goldberg SM, Madoff RD. Cutting seton versus two-stage seton fistulotomy in the surgical management of high anal fistula. Br J Surg. 1998;85:243-5.

9. Hamalainen KP, Sainio AP. Cutting seton for anal fistulas: high risk of minor control defects. Dis Colon Rectum. 1997;40:1443-7.

10. Hammond TM, Grahn MF, Lunniss PJ. Fibrin glue in the management of anal fistulae. Colorectal Dis. 2004;6:308-19.

11. Hoy HA, Williams JG. Outcome of surgery for complex anal fistula. Colorectal Dis. 2002;4:254-61.

12. Kodner IJ, Mazor A, Shemesh EI, Fry RD, Fleshman JW, Birnbaum EH. Endorectal advancement flap repair of rectovaginal and other complicated anorectal fistulas. Surgery. 1993;114:682-90.
13. Lindsey I, Smilgin-Humphreys MM, Cunningham C, Mortensen NJ, George BD. A randomized, controlled trial of fibrin glue $v s$. conventional treatment for anal fistula. Dis Colon Rectum. 2002;45:1608-15.

14. Lopes-Paulo F. O emprego da cola de fibrina no tratamento das fístulas anais. Rev Bras Coloproctol. 2006:26:86-8.

15. Loungnarath R, Dietz DW, Mutch MG Birnbaum EH, Kodner IJ, Fleshman JW. Fibrin glue treatment of complex anal fistulas has low success rate. Dis Colon Rectum. 2004;47:432-6.

16. Mizrahi N, Wexner SD, Zmora O, Da Silva G, Efron J, Weiss EG, Vernava AM 3rd, Nogueras JJ. Endorectal advancement flap: are there predictors of failure? Dis Colon Rectum. 2002;45:1616-21.

17. Parks AG, Gordon PH, Hardcastle JE. A classification of fistula-in-ano. Br J Surg. 1976;63:1-12

18. Pearl RK, Andrews JR, Orsay CP, Weisman RI, Prasad ML, Nelson RL, Cintron JR, Abcarian H. Role of the seton in the management of anorectal fistulas. Dis Colon Rectum. 1993;36:573-9.

19. Sentovich SM. Fibrin glue for all anal fistulas. J Gastrointest Surg. 2001;5: 158-61.

20. Swinscoe MT, Ventakasubramaniam DG, Jayne DG. Fibrin glue for fistula-inano: the evidence reviewed. Tech Coloproctol. 2005;9:89-94.

21. Whiteford MH, Kilkenny J $3^{\text {rd }}$, Hyman N, Buie WD, Cohen J, Orsay C, Dunn G, Perry WB, Ellis CN, Rakinic J, Gregorcyk S, Shellito P, Nelson R, Tjandra JJ, Newstead G. Practice parameters for treatment of perianal abscess and fistulain-ano (revised). Dis Colon Rectum. 2005;48:1337-42.

22. Williams JG, MacLeod CA, Rothenberger DA, Goldberg SM. Seton treatment of high anal fistulae. Br J Surg. 1991;78:1159-61.

23. Zmora O, Mizrahi N, Rotholtz N, Pikarsky AJ, Weiss EG, Nogueras JJ, Wexner SD. Fibrin glue sealing in the treatment of perineal fistulas. Dis Colon Rectum. 2003;46:584-9. 